\title{
A study on assessment of hydrocarbon potential of the lignite deposits of Saurashtra basin, Gujarat (Western India)
}

\author{
Prakash K. Singh ${ }^{1} \cdot$ V. K. Singh ${ }^{1} \cdot$ P. K. Rajak ${ }^{1} \cdot$ Neeraj Mathur ${ }^{2}$
}

Received: 8 May 2017/Revised: 27 August 2017/Accepted: 8 November 2017/Published online: 30 November 2017

(C) The Author(s) 2017. This article is an open access publication

\begin{abstract}
In the present investigation, Bhavnagar lignites of the Saurashtra basin (Gujarat) have been studied to assess their hydrocarbon generating potential. The samples of upper as well as lower lignite seams have been studied through microscopy and subjected to various chemical analyses viz. proximate analysis, ultimate analysis and Rock-Eval Pyrolysis. These lignites have high moisture and low to moderate ash yield but are characterized by high volatile matter. Petrographically they comprise predominantly of huminite group maceral while liptinite and inertinite groups occur in subordinated amount. Huminite is chiefly composed of detrohuminite and telohuminite. The $T_{\max }\left(\mathrm{av} .416 .23{ }^{\circ} \mathrm{C}\right.$ ) and huminite reflectivity $(0.28 \%-0.30 \%)$ indicate a low degree of maturity for these lignites which is also substantiated by the $T_{\max }$ versus hydrogen index plot. The organic matter is subjugated by kerogen Type-III with a potential to expel hydrocarbon on liquefaction. Study further reveals that the fixed hydrocarbon is several folds higher than the free hydrocarbons. Being high in reactive maceral content, a high 'conversion' and good 'oil yield' values for these lignites were observed. Thus, the empirically derived values match well with those obtained through the experimental values of Rock-Eval Pyrolysis and validate their hydrocarbon generating potential.
\end{abstract}

Keywords Saurashtra lignite $\cdot$ Reactive maceral $\cdot$ Rock-Eval $\cdot$ Hydrocarbon generating potential

\section{Introduction}

Gujarat is rich in lignite resources which occur in Cambay, Kachchh and Saurashtra basins and are of Eocene age. Gujarat lignites have been studied by Sahni et al. (2006), Samant (2000), Singh (2012), Singh and Singh (2005), Singh et al. (2010a, b, 2012a, b, 2016a, 2017a, b, c), and Thakur et al. (2010). Sahni et al. (2006) have discussed that these lignite deposits have been formed on the Plate margin of India as a result of the withdrawal of the Neotethys in

Prakash K. Singh

prakashbhu@rediffmail.com

1 Coal and Organic Petrology Lab, Centre of Advanced Study in Geology, Banaras Hindu University, Varanasi, Uttar Pradesh 221005, India

2 Centre of Excellence for Energy Studies, Oil India Limited, Rukminigaon, GS Road, Guwahati, Assam 781022, India
Pakistan, western India, northern India and north-eastern India. It is believed that during the Late Paleocene-Middle Eocene period a warmer period prevailed causing an increase in the deep sea water temperature by $6{ }^{\circ} \mathrm{C}$. It started as the Paleocene Eocene Thermal Maximum (PETM) and subsequently there was an Early Eocene Climatic Optimum (EECO) resulting into faunal and floral changes in several parts of the world (Kennet and Stott 1991; Koch et al. 1992; Katz et al. 1999; Schmitz et al. 2001). The productivity of organic matter increased multifold which eventually formed lignite/coal deposits in the western margin of India. It also continued even in Pakistan.

Though, petro-chemical and petro-thermal studies of Indian Tertiary coals have been attempted on few samples (Sharma et al. 2016; Baruah et al. 2013), meagre data is available on the hydrocarbon evaluation of the Tertiary coal and lignite resources of the country. The present investigation entails the results of various analyses carried 
out on the Bhavnagar lignites of the Saurashtra basin. Both, petrographic as well as chemical data have been used to evaluate the hydrocarbon potential of these lignites. Further, the experimental data has been compared and correlated with the empirically drawn values to cross examine the potential. The study would be a new insight for the future research.

\section{Geological setting}

The Arabian Sea bounds the Saurashtra peninsula from all the sides except north-eastern side. This basin preserves the sedimentary records from Juro-Cretaceous to recent age and the peninsular block is actually a faulted cratonic horst which is surrounded by rift grabens (Biswas 1982). This includes the western Cambay basin border fault, the Kachchh rift fault, the Narmada rift extension and west coast fault. Several small faults also occur in the area and the entire Tertiary sediments are affected by folding and faulting owing to the block movement along the major faults. Cone-and-crater type physiography prevails in the Saurashtra peninsula having a prominent central highland. Formation of varied rock types from a single lava mass as a result of magmatic differentiation makes it geologically interesting which cover nearly two-third of the area of the peninsula. This forms the basement for the deposition of Tertiary sediments. The fringes of the Saurashtra peninsula are covered by the marine Tertiary rocks. The sedimentation is marked by several unconformities. The lignite bearing sequence occurs in Khadsaliya Clay Formation which comprises greenish-grey clay formation of Eocene age and occurs at a depth of 22-195 m. There are two subsurface horizons which are referred to as, top lignite horizon, and bottom lignite horizon. The top horizon is $0.1-13 \mathrm{~m}$ thick and continues throughout the area but the bottom is $0.2-4 \mathrm{~m}$ thick and discontinuous in nature. This basin is estimated to have a total lignite reserve of 107.5 million tonnes. The general stratigraphic succession of the area is provided in Table 1 while a geological map of Saurashtra basin is shown in Fig. 1.

\section{Method of study}

Lignite samples were collected following the pillar sampling method of Schopf (1960) from lower as well as upper seams from the Surkha lignite mine (Bhavnagar) in Saurashtra basin, Gujarat (Fig. 1). The samples represent full seam thickness which could be reconstructed in the laboratory. On the basis of similar megascopic characters, the lignite samples were clubbed together forming composite bands. In the present investigation, each composite
Table 1 General stratigraphic succession in the Saurashtra basin, Gujarat (after Srivastava 1963)

\begin{tabular}{|c|c|c|}
\hline Formations & Lithology & Age \\
\hline Recent deposits & $\begin{array}{l}\text { Soil and Alluvium Coastal } \\
\text { dunes and beach sands } \\
\text { Unconformity }\end{array}$ & $\begin{array}{l}\text { Recent and } \\
\text { sub-recent }\end{array}$ \\
\hline $\begin{array}{l}\text { Lakhanka Formation } \\
\text { (Agate } \\
\text { Conglomerate } \\
\text { formation) }\end{array}$ & $\begin{array}{l}\text { Agate bearing } \\
\text { conglomerates } \\
\text { ferrugenous sandstones } \\
\text { and loose sand } \\
\text { Unconformity }\end{array}$ & $\begin{array}{l}\text { Pleistocene } \\
\text { to sub- } \\
\text { recent }\end{array}$ \\
\hline Piram beds & $\begin{array}{l}\text { Fossiliferous conglomerates } \\
\text { Grits and sandy clays } \\
\text { Unconformity }\end{array}$ & $\begin{array}{l}\text { Uppermost } \\
\text { miocene } \\
\text { to } \\
\text { pliocene }\end{array}$ \\
\hline Gaj formation & $\begin{array}{l}\text { Variegated shales with } \\
\text { gypsum veinlets, sand } \\
\text { stones, amrls and } \\
\text { conglomerates } \\
\text { Unconformity }\end{array}$ & $\begin{array}{l}\text { Lower } \\
\text { miocene }\end{array}$ \\
\hline $\begin{array}{l}\text { KhadsaliyaClays } \\
\text { Supratrapean }\end{array}$ & $\begin{array}{l}\text { Grey to greenish grey clays } \\
\text { sandstone, lignite with or } \\
\text { without siderite nodules } \\
\text { Unconformity } \\
\text { Laterite, lithomarge, } \\
\text { bentonite } \\
\text { Unconformity }\end{array}$ & $\begin{array}{l}\text { Eocene } \\
\text { lower } \\
\text { eocene }\end{array}$ \\
\hline Deccan Trap & $\begin{array}{l}\text { Plutonic masses and dykes } \\
\text { intrusive in the trap flows } \\
\text { Unconformity }\end{array}$ & $\begin{array}{l}\text { Cretaceous } \\
\text { to eocene }\end{array}$ \\
\hline
\end{tabular}

band has been treated as one sample and assigned a sample number. The samples were crushed, reduced in quantity through quartering and coning, and subjected to various analyses. The polished mounts were prepared for petrography using -18 mesh size coal particles while -70 mesh size powders was used for proximate and other chemical analyses. Maceral analysis was performed using a Leitz Orthoplan-Pol Microscope equipped with Wild Photoautomat MPS-45 in the "Coal and Organic Petrology Laboratory', Department of Geology, Banaras Hindu University. White light was sourced from a $12 \mathrm{~V} / 100 \mathrm{~W}$ halogen lamp while fluoroscopy was performed using Ploemopak with filter block I $2 / 3$ having blue excitation filters (BP450-490), dinomatic mirror (RKP510) and suppression filter (LP520). The methodology described by Taylor et al. (1998) was adopted. Huminite macerals were termed and described as per ICCP-1994 (Sykorova et al. 2005), while the description provided by the ICCP (2001) was followed for inertinite macerals. The huminite reflectance measurement was conducted at National Metallurgical Laboratory, Jamshedpur following ISO 7404-5:2009. 


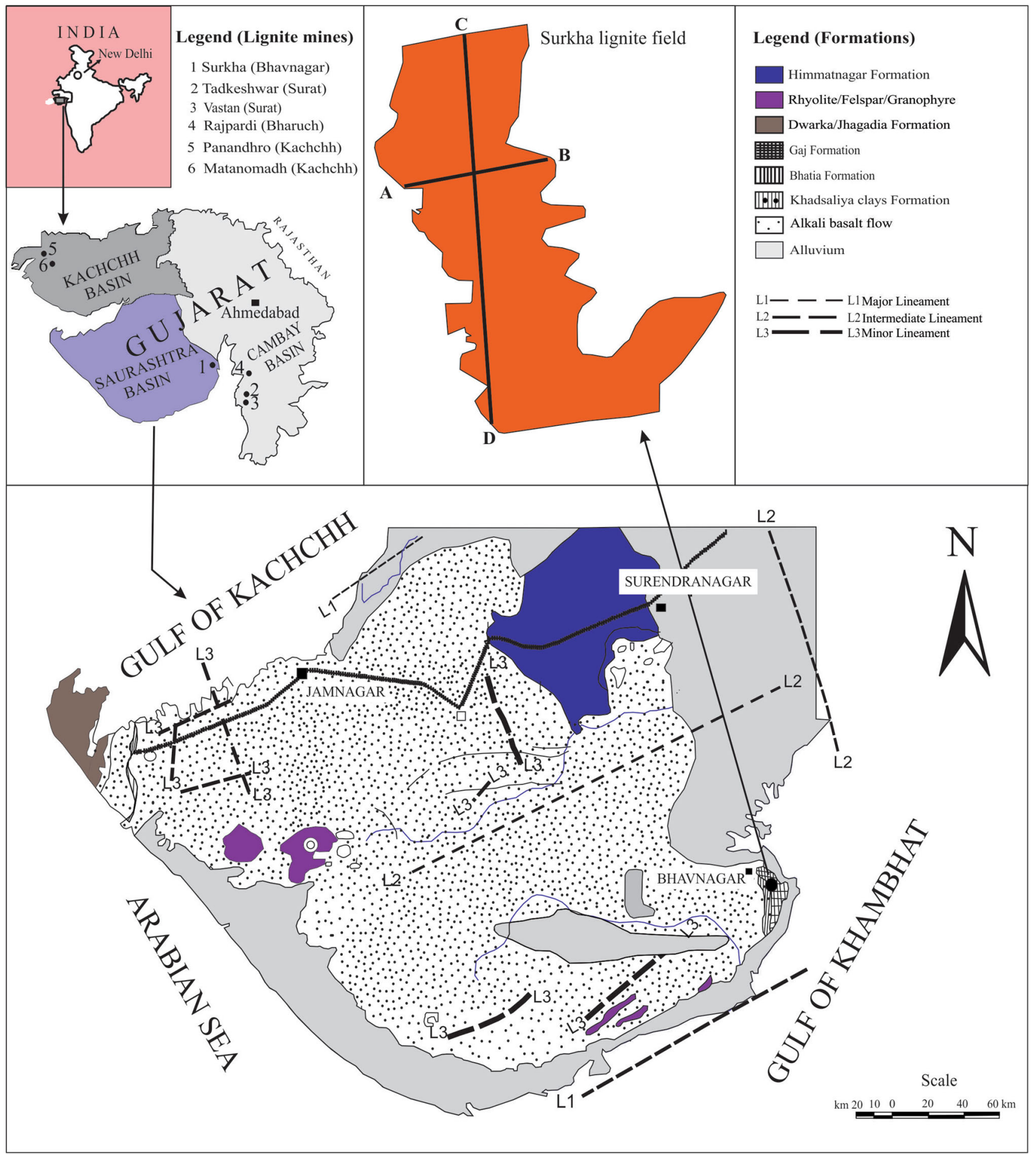

Fig. 1 Geological map of Saurashtra basin (redrawn after GSI 2012) and location of lignite mines

\section{Results}

\subsection{Chemical attributes}

Chemical constituents of Bhavnagar lignite are furnished in Table 2. Proximate analysis reveals that the upper lignite seam has $>21 \%$ moisture, $>10 \%$ ash yield and $>57 \%$ volatile matter (daf basis) while the lower lignite seam is characterized by $>29 \%$ moisture, $8 \%$ ash yield and $>66 \%$ volatile matter (daf basis). Moreover, these lignite seams contain $>70 \%$ elemental carbon and their sulphur content is moderately high ( $>2 \%$ in some samples). 
Table 2 Petrographic and chemical constituents of the lignites of Saurashtra basin, Gujarat

\begin{tabular}{|c|c|c|c|c|c|c|c|c|c|c|c|c|c|}
\hline \multirow[t]{2}{*}{ S. no. } & \multirow[t]{2}{*}{ Humi } & \multirow[t]{2}{*}{ Lipt } & \multirow[t]{2}{*}{ Inert } & \multirow{2}{*}{$\begin{array}{l}\text { Mineral } \\
\text { Matter }\end{array}$} & \multirow[t]{2}{*}{$\mathrm{VRr}$} & \multirow{2}{*}{$\begin{array}{l}\text { Ash } \\
(\%)\end{array}$} & \multicolumn{2}{|c|}{ Dry ash free } & \multicolumn{4}{|c|}{ Dry ash free } & \multirow[t]{2}{*}{$S^{\text {dry }}$} \\
\hline & & & & & & & $\begin{array}{l}\text { Volatile } \\
\text { Matter }\end{array}$ & $\begin{array}{l}\text { Fixed } \\
\text { Carbon }\end{array}$ & $\mathrm{C}$ & $\mathrm{H}$ & $\mathrm{N}$ & $\mathrm{O}$ & \\
\hline \multicolumn{14}{|c|}{ Bhavnagar upper seam } \\
\hline Top BH10 & $68.1(83.8)$ & $8.6(10.5)$ & $4.6(5.6)$ & 18.7 & 0.27 & 10.07 & 59.19 & 40.81 & 62.44 & 5.15 & 0.78 & 29.48 & 1.89 \\
\hline BH9 & $76.8(87.5)$ & $6.6(7.5)$ & $4.4(5.0)$ & 12.2 & & 10.33 & 62.36 & 37.64 & & & & & \\
\hline BH8 & $66.7(81.9)$ & $7.8(9.6)$ & $7(8.6)$ & 18.6 & & 10.15 & 60.59 & 39.41 & & & & & \\
\hline $\mathrm{BH} 7$ & $64.7(83.5)$ & $10(12.9)$ & $2.8(3.6)$ & 22.6 & & 10.57 & 59.57 & 40.43 & & & & & \\
\hline BH6 & $67.9(87.2)$ & $7.2(9.2)$ & $2.8(3.6)$ & 22.2 & & 9.79 & 53.97 & 46.03 & & & & & \\
\hline BH5 & $69(83.9)$ & $7.8(9.5)$ & $5.4(6.6)$ & 17.8 & 0.31 & 9.52 & 60.69 & 39.31 & 82.99 & 5.49 & 0.97 & 8.77 & 1.57 \\
\hline BH4 & $71(90.8)$ & $4.8(6.1)$ & $2.4(3.1)$ & 21.8 & & 8.43 & 48.94 & 51.06 & & & & & \\
\hline BH3 & $69.3(89.9)$ & $4.6(5.9)$ & $3.2(4.1)$ & 22.9 & & 10.05 & 49.63 & 50.4 & & & & & \\
\hline $\mathrm{BH} 2$ & $66.1(84.2)$ & $7.2(9.2)$ & $5.2(6.6)$ & 21.6 & & 10.08 & 59.26 & 40.74 & & & & & \\
\hline $\begin{array}{l}\text { Bottom } \\
\text { BH1 }\end{array}$ & $65.7(80.8)$ & $10.4(12.8)$ & $5.2(6.4)$ & 18.8 & 0.26 & 14.59 & 58.12 & 41.78 & 73.34 & 3.41 & 1.06 & 19.51 & 2.16 \\
\hline Mean & $68.5(85.4)$ & $7.5(9.3)$ & $4.3(5.3)$ & 19.7 & 0.28 & 10.36 & 57.23 & 42.76 & 72.92 & 4.68 & 0.94 & 19.25 & 1.87 \\
\hline \multicolumn{14}{|c|}{ Bhavnagar lower seam } \\
\hline $\begin{array}{l}\text { Top } \\
\text { BHL9 }\end{array}$ & $65.5(80)$ & $11.8(14.4)$ & $4.6(5.6)$ & 18.2 & 0.29 & 10.34 & 68.19 & 31.81 & 68.14 & 4.87 & 1.07 & 23.28 & 2.27 \\
\hline BHL8 & $61.2(74.8)$ & $14.8(18.1)$ & $5.8(7.1)$ & 18.2 & & 6.63 & 74.25 & 25.75 & & & & & \\
\hline BHL7 & $56.6(75.5)$ & $10.2(13.6)$ & $8.2(10.9)$ & 25 & & 7.86 & 65.81 & 34.19 & & & & & \\
\hline BHL6 & $48.4(57.1)$ & $15.2(17.9)$ & $21.2(25)$ & 15.2 & & 8.51 & 64.06 & 35.94 & & & & & \\
\hline BHL5 & $60.2(76.8)$ & $8.2(10.5)$ & $10(12.8)$ & 21.6 & 0.30 & 7.79 & 64.14 & 35.86 & & & & & \\
\hline BHL4 & 77 (85.6) & $8(8.8)$ & $5(5.5)$ & 10 & & 8.4 & 59.75 & 40.25 & & & & & \\
\hline BHL3 & $56.4(78.6)$ & $10.6(14.8)$ & $4.8(6.7)$ & 28.2 & & 5.86 & 62.17 & 37.83 & & & & & \\
\hline BHL2 & $66.8(79)$ & $10.2(12.1)$ & $7.6(9)$ & 15.4 & & 10.37 & 73.43 & 26.57 & & & & & \\
\hline $\begin{array}{l}\text { Bottom } \\
\text { BHL1 }\end{array}$ & $60.3(80.5)$ & $10(13.3)$ & $4.6(6.1)$ & 25.1 & 0.32 & 8.02 & 70.19 & 29.81 & 72.69 & 6.05 & 1.09 & 18.38 & 1.61 \\
\hline Mean & $61.4(76.4)$ & 11 (13.7) & $8.0(9.9)$ & 19.7 & 0.30 & 8.2 & 66.89 & 33.11 & 70.41 & 5.46 & 1.08 & 20.83 & 1.94 \\
\hline
\end{tabular}

Values in parenthesis are recalculated on m.m.f. basis. Humi-Huminite; Lipti-Liptinite; Inerti- inertinite

\subsection{Petrographic constituents}

Detailed petrographic characteristics have been discussed by Singh et al. (2017a) and the constituents are provided in Table 2. In upper lignite seam, huminite $(80.8 \%-90.8 \%$; av. $85.4 \% \mathrm{mmf}$ basis) comprises mainly of detrohuminite (av. $37.9 \%$ densinite, and av. $21.9 \%$ attrinite on $\mathrm{mmf}$ basis) followed by telohuminite (av 10.7\% ulminite-A and 7.8\% ulminite-B on mmf basis). Liptinites (av. 9.3\% mmf basis) and inertinites (av. 5.3\% mmf basis) occur in relatively low amount. A moderate quantity of mineral matter (av. 19.7\%) occurs in this seam. Similarly in lower lignite seam, huminite (av. 76.4\% mmf basis) is the dominant maceral group which is largely contributed by detrohuminite. This is represented mostly by densinite (av. $24.1 \% \mathrm{mmf}$ basis) and attrinite (av. 20.7\% mmf basis) while Telohuminite is primarily represented by ulminite-B (av. $16.9 \% \mathrm{mmf}$ basis) and ulminite-A (av. 8.7\% mmf basis). Macerals of the liptinite (av. 13.7\% $\mathrm{mmf}$ basis) and inertinite (av. 9.9\% mmf basis) groups occur in subordinated amount while the mineral matter content is moderate (av. 19.7\%).

\subsection{Rock-Eval pyrolysis}

Rock-Eval analysis of the investigated samples is furnished in Table 3 while the interpretative guidelines of Rock-Eval data are provided in Table 4. The total organic carbon (TOC), in the lignites of Saurashtra basin, ranges from $38.41 \%$ to $41.91 \%$ (av. $40.16 \%$ ), while $T_{\max }$ value ranges from 414.13 to $418.33{ }^{\circ} \mathrm{C}$ (av. $416.23{ }^{\circ} \mathrm{C}$ ). The value of $\mathrm{S}_{1}$ peak (free hydrocarbons) ranges from 2.83 to $3.35 \mathrm{mg} \mathrm{HC} /$ g (av. $3.09 \mathrm{mg} \mathrm{HC} / \mathrm{g}$ ). Similarly, $\mathrm{S}_{2}$ peak (fixed hydrocarbons) ranges from 81.63 to $100.24 \mathrm{mg} \mathrm{HC} / \mathrm{g}$ (av. $90.94 \mathrm{mg}$ $\mathrm{HC} / \mathrm{g}$ ), and $\mathrm{S}_{3}$ peak (carbon dioxide) ranges from 20.42 to 
Table 3 Rock-Eval data of the lignite samples of Saurashtra basin, Gujarat

\begin{tabular}{|c|c|c|c|c|c|c|c|c|c|c|c|c|}
\hline S. No. & $\begin{array}{l}\text { Sample } \\
\text { No. }\end{array}$ & $T_{\max }\left({ }^{\circ} \mathrm{C}\right)$ & $\begin{array}{l}\mathrm{S}_{1}(\mathrm{mg} \\
\mathrm{HC} / \mathrm{g})\end{array}$ & $\begin{array}{l}\mathrm{S}_{2}(\mathrm{mg} \\
\mathrm{HC} / \mathrm{g})\end{array}$ & $\begin{array}{l}\mathrm{S}_{3}(\mathrm{mg} \\
\mathrm{CO} 2 / \mathrm{g})\end{array}$ & PI & $\mathrm{S}_{2} / \mathrm{S}_{3}$ & P.C. & $\begin{array}{l}\text { TOC }(100 \times \\
\mathrm{g} \mathrm{C} / \mathrm{g})\end{array}$ & $\begin{array}{l}\mathrm{HI}(\mathrm{mg} \mathrm{HC} / \mathrm{g} \\
\text { TOC) }\end{array}$ & $\begin{array}{l}\mathrm{OI}(\mathrm{mg} \mathrm{CO} 2 / \\
\mathrm{g} \text { TOC) }\end{array}$ & $\begin{array}{l}\text { MINC } \\
(\%)\end{array}$ \\
\hline 1 & BH10 & 410.00 & 4.26 & 78.43 & 21.10 & 0.05 & 82.69 & 6.86 & 44.47 & 176.00 & 47.00 & 1.56 \\
\hline 2 & BH9 & 409.00 & 0.71 & 59.28 & 21.70 & 0.01 & 59.99 & 4.98 & 42.78 & 139.00 & 51.00 & 1.52 \\
\hline 3 & BH8 & 415.00 & 0.19 & 53.15 & 19.77 & 0.00 & 53.34 & 4.43 & 38.12 & 139.00 & 52.00 & 1.35 \\
\hline 4 & BH7 & 412.00 & 8.08 & 119.85 & 23.83 & 0.06 & 127.93 & 10.62 & 45.25 & 265.00 & 53.00 & 1.99 \\
\hline 5 & BH5 & 418.00 & 11.05 & 207.12 & 15.37 & 0.05 & 218.17 & 18.11 & 47.28 & 438.00 & 33.00 & 1.30 \\
\hline 6 & $\mathrm{BH} 4$ & 415.00 & 0.00 & 34.66 & 22.46 & 0.00 & 34.66 & 2.88 & 40.56 & 85.00 & 55.00 & 1.57 \\
\hline 7 & $\mathrm{BH} 3$ & 417.00 & 0.00 & 28.16 & 21.01 & 0.00 & 28.16 & 2.34 & 38.05 & 74.00 & 55.00 & 1.35 \\
\hline 8 & BH1 & 417.00 & 2.51 & 72.38 & 18.12 & 0.03 & 74.89 & 6.22 & 38.78 & 187.00 & 47.00 & 1.37 \\
\hline Mean & & 414.13 & 3.35 & 81.63 & 20.42 & 0.03 & 84.98 & 7.05 & 41.91 & 187.88 & 49.13 & 1.50 \\
\hline 9 & BHL9 & 417.00 & 1.78 & 69.61 & 22.09 & 0.02 & 71.39 & 5.93 & 36.03 & 193.00 & 61.00 & 2.40 \\
\hline 10 & BHL5 & 418.00 & 1.12 & 65.93 & 21.46 & 0.02 & 67.05 & 5.57 & 37.20 & 177.00 & 58.00 & 2.64 \\
\hline 11 & BHL1 & 420.00 & 5.58 & 165.19 & 19.02 & 0.03 & 170.77 & 14.17 & 42.00 & 393.00 & 45.00 & 2.14 \\
\hline Mean & & 418.33 & 2.83 & 100.24 & 20.86 & 0.02 & 103.07 & 8.55 & 38.41 & 254.33 & 54.67 & 2.39 \\
\hline
\end{tabular}

BH Bhavnagar upper lignite seam; $B H L$ Bhavnagar lower seam

Table 4 Interpretative guidelines of Rock-Eval pyrolysis obtained through geochemical parameters (based on Peters 1986)

\begin{tabular}{|c|c|c|c|c|}
\hline Properties revealed & Quality & TOC \% & $\mathrm{S}_{1}(\mathrm{mg} \mathrm{HC} / \mathrm{g}$ rock $)$ & $\mathrm{S}_{2}(\mathrm{mg} \mathrm{HC} / \mathrm{g}$ rock $)$ \\
\hline \multirow[t]{4}{*}{ Source rock generative potential } & Poor & $0-0.5$ & 0.5 & $0-0.5$ \\
\hline & Fair & $0.5-1.0$ & $0.5-1.0$ & $2.5-5.0$ \\
\hline & Good & $1-2$ & $1-2$ & $5-10$ \\
\hline & Very good & $>2$ & $>2$ & $>10$ \\
\hline \multirow[t]{4}{*}{ Type of hydrocarbon generated } & Type & & HI (mg HC/Org) & $\mathrm{S} 2 / \mathrm{S} 3$ \\
\hline & Gas & & $0-150$ & $0-3$ \\
\hline & Gas + Oil & & $150-300$ & $3-5$ \\
\hline & Oil & & $>300$ & $>5$ \\
\hline \multirow[t]{3}{*}{ Level of thermal maturation } & Maturation & $\mathrm{PI}=\mathrm{S} 1 /(\mathrm{S} 1+\mathrm{S} 2)$ & $\mathrm{T} \max { }^{\circ} \mathrm{C}$ & Ro $\%$ \\
\hline & Top oil window (Birth line) & -0.1 & $435-445$ & 0.6 \\
\hline & Bottom oil window (dead line) & -0.4 & 470 & 1.4 \\
\hline
\end{tabular}

$20.86 \mathrm{mg} \mathrm{CO} / \mathrm{g}$ (av. $20.64 \mathrm{mg} \mathrm{CO}_{2} / \mathrm{g}$ ). The Hydrogen Index (HI) ranges from 187.88 to 254.33 (av. 221.10), while the Oxygen Index (OI) ranges from 49.13 to 54.67 (av. 51.90), and the Production Index (PI) ranges from 0.02 to 0.03 (av. 0.03). The mineral carbon (TIC) varies from $1.50 \%$ to $2.39 \%$ (av. $1.95 \%$ ).

\section{Discussion}

The upper lignite seam megascopically comprises of unstratified brown bands while the lower seam has alternately stratified and unstratified brown bands. Resin patches are visibly seen in the lignite samples. Huminite group macerals predominantly occur in these lignites of
Saurashtra basin while liptinite and inertinite group macerals occur in subordinated amounts. While the cell lumens of textinite are filled with argillaceous minerals and occasionally with gelinite or corpohuminite, ulminite is homogeneous but several patches show cracks and fractures developed in it. Clustered corpohuminites are frequently associated with ulminite and are occasionally oxidized. Resinite, sporinite and cutinite are common liptinite macerals in these lignites. Suberinite showing developed cortex cells and massive bituminite grains are also observed. Funginite is the common inertinite maceral in these lignites and occur as single chambered as well as multichambered oval bodies. Characteristic macerals of the Saurashtra basin are shown in Fig. 2. 

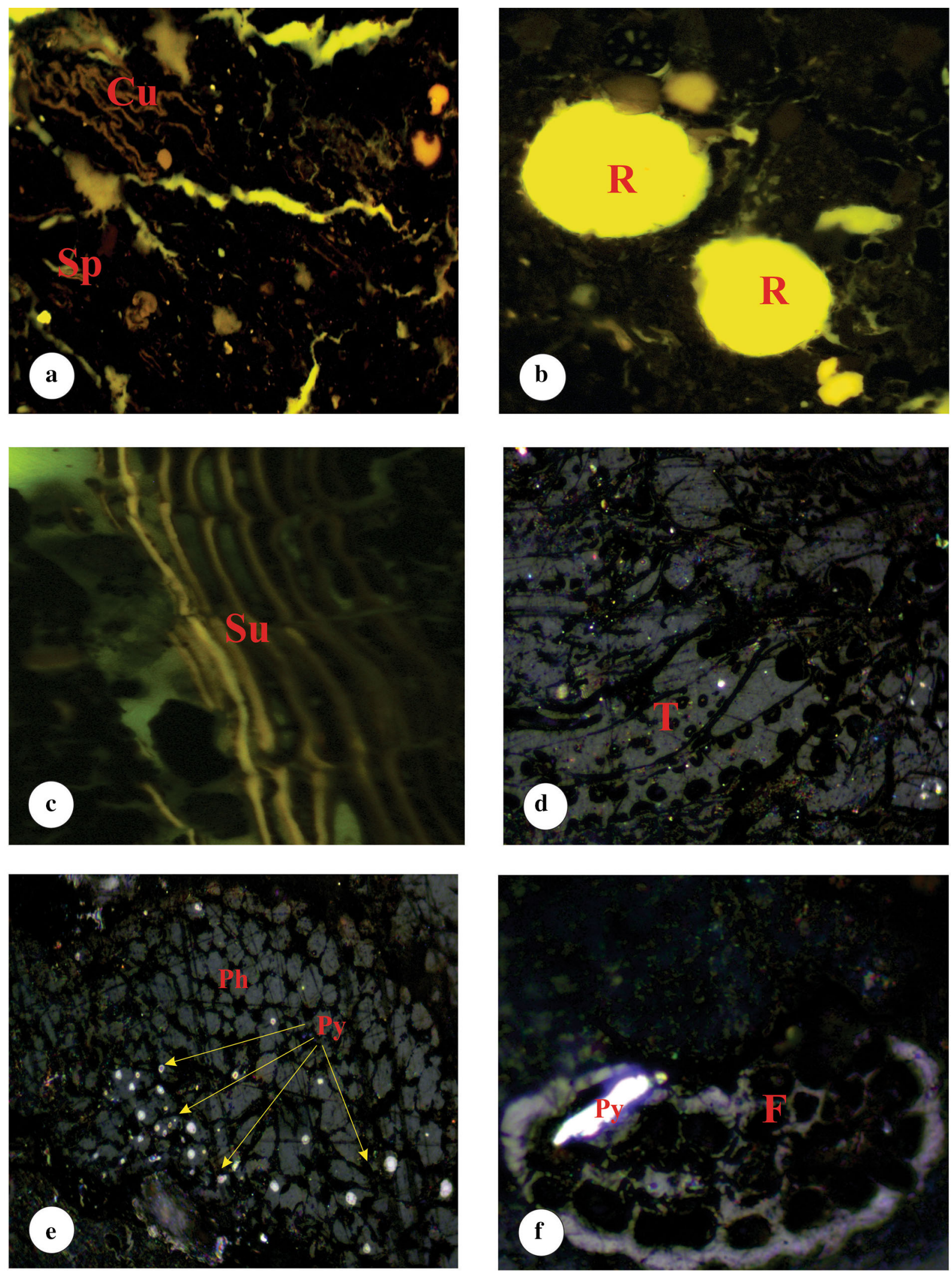

$50 \mu \mathrm{m}$

Fig. 2 Characteristic photomicrographs in lignites of Saurashtra basin: a cutuinite $(\mathrm{Cu})$ and sporinite; b resinite $(\mathrm{R})$ grains; $\mathbf{c}$ suberinite $(\mathrm{Su})$; d textinite $(\mathrm{T})$ with oxidation craks; e phlopaphinite $(\mathrm{Ph})$ and pyrite $(\mathrm{Py})$; f fungnite $(\mathrm{F})$ and pyrite $(\mathrm{Py})$ 


\subsection{Maturity of lignites of Saurashtra basin and their hydrocarbon potential}

Since lignite is being considered as a source rock for oil generation in the present investigation it is important to understand its rank and maturity separately. While the former provides information about the degree of coalification, the latter would help in knowing the degree to which the oil potential of these lignites has lessened with increasing thermal stress. The Eocene lignites of Saurashtra have $0.28 \%-0.30 \% \mathrm{VRr}$ which put them as 'low rank C' coals (ISO 2005). Huminite reflectance maintains an ascending trend with carbon (daf) content $(r=0.295)$ while $\mathrm{VR}_{\max }$ has a decreasing trend $(r=-0.47)$ with volatile matter (daf). A similar trend was also reported in the Indonesian coals by Amijaya and Littke (Amijaya and Littke 2005).

Though insignificant in number yet many oil basins of the world are associated with coal bearing sequences (Powell and Boreham 1994). Kutei basin of Indonesia and the Gibbsland basin of Australia (Macgregar 1994) may be listed as examples of such sequences. Thomas (2002) has discussed that $80 \%$ of Australian oil and $10 \%-30 \%$ of south-east Asian oil is sourced from the coal bearing sequences. Thick Tertiary deposits occur in the northern part of the German gas province where the coal bearing source rocks have generated huge quantity of gas which is preserved in the reservoirs (Teichmüller et al. 1984). Moreover, coal bearing Carboniferous is the main gas source rock for the deeper reservoirs in the region between Wales and Ruhr Basin (Teichmüller et al. 1984 as discussed in Taylor et al. 1998). Significance of oil exploration lies in the proper evaluation of hydrocarbon potential (Dow 1974) because a good hydrocarbon reserve only forms when there are good source rock, favourable depositional and tectonic structure, and proper thermal maturation (Otis and Schneidermann 1997). Wilkins and George (2002) have made comprehensive review and discussed the potential of coal to generate oil. Coal properties required for the liquefaction of coal have been discussed by Cudmore (1977) and accordingly the characteristics of the investigated lignites are provided in Table 5. While working on Danish Central Graben coals, Petersen et al. $(1996,1998)$ demonstrated that a maximum average content of free and fixed hydrocarbons $\left(\mathrm{S}_{1}+\mathrm{S}_{2}\right)$ and $\mathrm{HI}$ values are found in the coals seams associated with a rapid sea level rise. Further, Noble et al. (1991) and Mukhopadhyay et al. (1991) observed that the coals formed in the delta plain are oil prone in nature. A similar situation holds good for the lignites of Saurashtra basin. Singh et al. (2016a, 2017a, b) have shown that the lignite deposits of Gujarat (Cambay, Kachchh and Saurashtra basins) and Rajasthan (Bikaner-Nagaur and Barmer basins) evolved
Table 5 Coal characteristics of the investigated area indicating its suitability for hydrogenation

\begin{tabular}{lllll}
\hline $\begin{array}{l}\text { S. } \\
\text { no. }\end{array}$ & $\begin{array}{l}\text { Properties of coal required for } \\
\text { hydrogenation (after Cudmore 1977) }\end{array}$ & \multicolumn{2}{l}{$\begin{array}{l}\text { Characteristic } \\
\text { of bhavnagar } \\
\text { lignite }\end{array}$} \\
\cline { 3 - 5 } & & Upper & Lower \\
\hline 1 & Vitrinite reflectance (VRr) & $<0.8$ & 0.28 & 0.30 \\
2 & H/C atomic ratio & $>0.75 \%$ & 0.78 & 0.93 \\
3 & Vitrinite + liptinite content & $>60 \%$ & 94.70 & 90.10 \\
4 & Volatile matter (daf) & $>35 \%$ & 57.23 & 66.89 \\
5 & $\begin{array}{c}\text { Concentration of } \\
\text { heteroatoms }\end{array}$ & $\begin{array}{c}\text { Relatively } \\
\text { low }\end{array}$ & Low & Low \\
& & & &
\end{tabular}

nd not determined

under coastal marshy setting with intermittent fluvial activities giving rise to a supratidal flood plain. Moreover, a eustatic rise of 70-140 $\mathrm{m}$ in the sea level during the Early Paleogene period, as compared to the present sea level, is suggested by Haq et al. (1987). This is indicated by global transgressions that occurred during 58.5-52.8 Ma.

Inception of Rock-Eval technique has opened a new window for the oil industries especially for characterizing the source rocks because it provides a rapid alternative method for determination of HC/OC indices. The cross plot (Fig. 3) between $T_{\max }$ and hydrogen index (HI) shows immaturity and terrestrial origin of the investigated lignites. The organic matter is chiefly characterized by kerogen Type-III with only a little amount of kerogen Type-II. This fact is also supported by the plot between HI and OI (Fig. 4) wherein the values fall between kerogen Type-III and Type-II. Generally, kerogen type III dominantly contains aromatic structures, heteroatomic ketones, and carboxylic acid groups and has a low proportion of aliphatic and alicyclic compounds. Type III kerogen is high gas prone as compared to types I and II. On the other hand, type II kerogen is characterized by high lipid content and is considered as an important constituent of source rock (Suárez-Ruiz and Crelling 2008). It contains a mixed proportion of aliphatic and aromatic structures and is oilprone in nature. Petersen $(2005,2006)$ demonstrated the potential of humic coals (kerogen Type-III) to expel hydrocarbon and similar studies were also carried out by Singh (2012) for Vastan and Rajpardi lignites (India), by Singh et al. (2013) for the East Kalimantan coals of Indonesia, by Raju and Mathur (2013) and by Singh et al. (2016b) for the Bikaner-Nagaur lignite basin (Rajasthan), and by Singh et al. (2016c) for the Cambay lignite basin (Gujarat). The cross plot, between $\mathrm{H} / \mathrm{C}$ and $\mathrm{O} / \mathrm{C}$ atomic ratios (Fig. 5) shows that the samples fall in the lignite and sub-bituminous range and have kerogen Type-III except one sample which is in the bituminous zone. This could be 


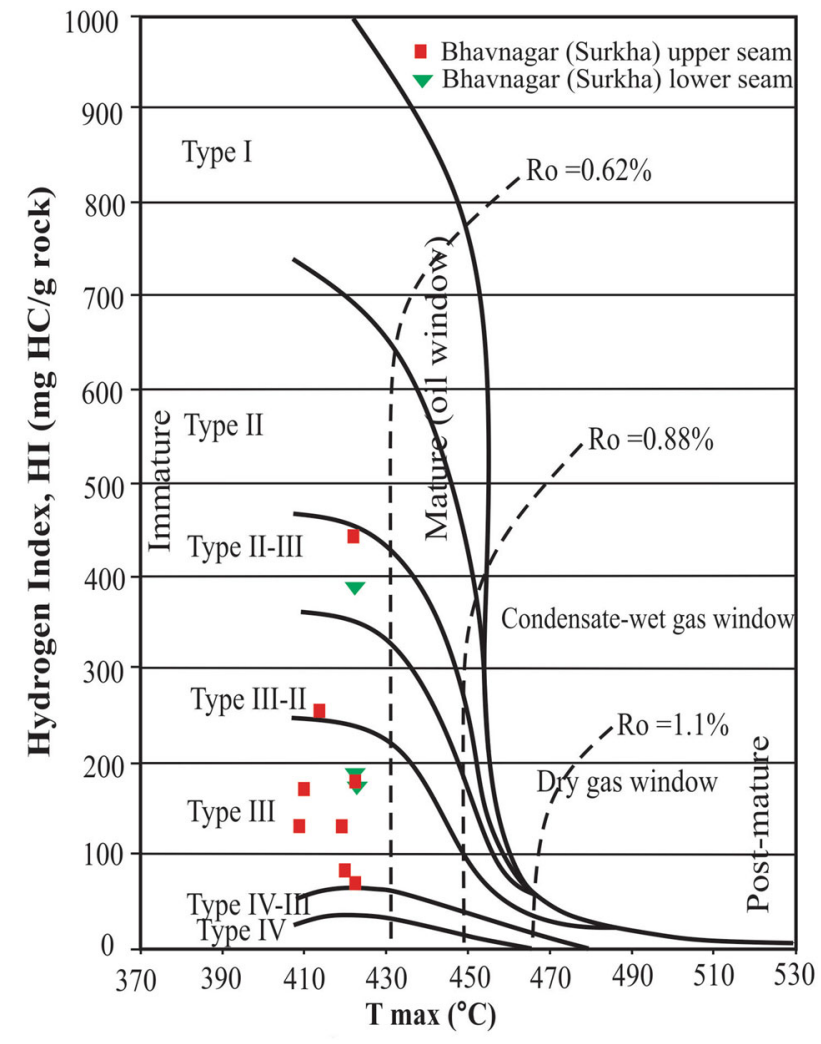

Fig. 3 Distribution of $T \max \left({ }^{\circ} \mathrm{C}\right)$ and hydrogen index (HI) of the analysed lignite samples of Saurashtra basin (adopted after Koeverdon et al. 2011)

due to localized effect leading to relatively enhanced coalification. This situation is also seen in the Seyler's diagram (Fig. 6). The hydrogen and carbon composition in Seyler's diagram indicates that the lignite samples of the Saurashtra basin are spread up in sub-hydrous to perhydrous range. The cross plot between huminite reflectance and hydrogen index (Fig. 7) shows that the lignite is mainly oil-prone in nature. The Rock-Eval data shows that the free hydrocarbon $\left(\mathrm{S}_{1}\right)$, distilled out of the samples at an initial heating of $300{ }^{\circ} \mathrm{C}$, varies from 2.83 to $3.35 \mathrm{mg} \mathrm{HC} / \mathrm{g}$ in the lignites of Saurashtra basin. This makes the Saurashtra lignite a good source rock considering $1 \mathrm{mg} \mathrm{HC/g}$ as cutoff value. The fixed hydrocarbons $\left(S_{2}\right.$ values) are many fold higher than the free hydrocarbons in the seams of Saurashtra basin. Considering 5 as cut-off value for $S_{2}$, it is a good source rock for hydrocarbon generation while the trapped carbon-dioxide $\left(\mathrm{S}_{3}\right)$ is proportional with the oxygen present in these lignites. Here, $S_{1}$ maintains a strong sympathetic linear relationship with $\mathrm{S}_{2}$ and complement each other $(r=0.926)$. With increasing content of free hydrocarbon, there is concomitant increase in the fixed hydrocarbon which is released during the thermal cracking of samples between 300 and $650{ }^{\circ} \mathrm{C}$ which also indicates a good hydrocarbon potential. The analysis reveals that the

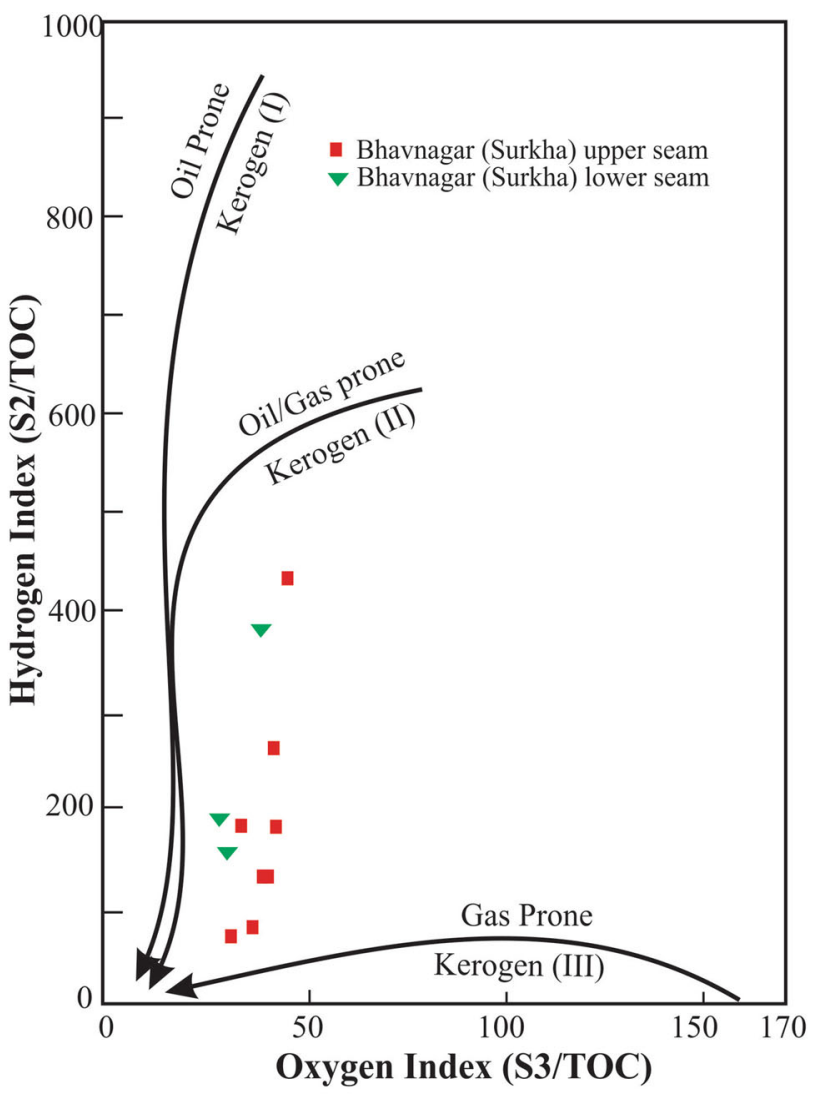

Fig. 4 Cross plot between hydrogen index (HI) and oxygen index (OI)

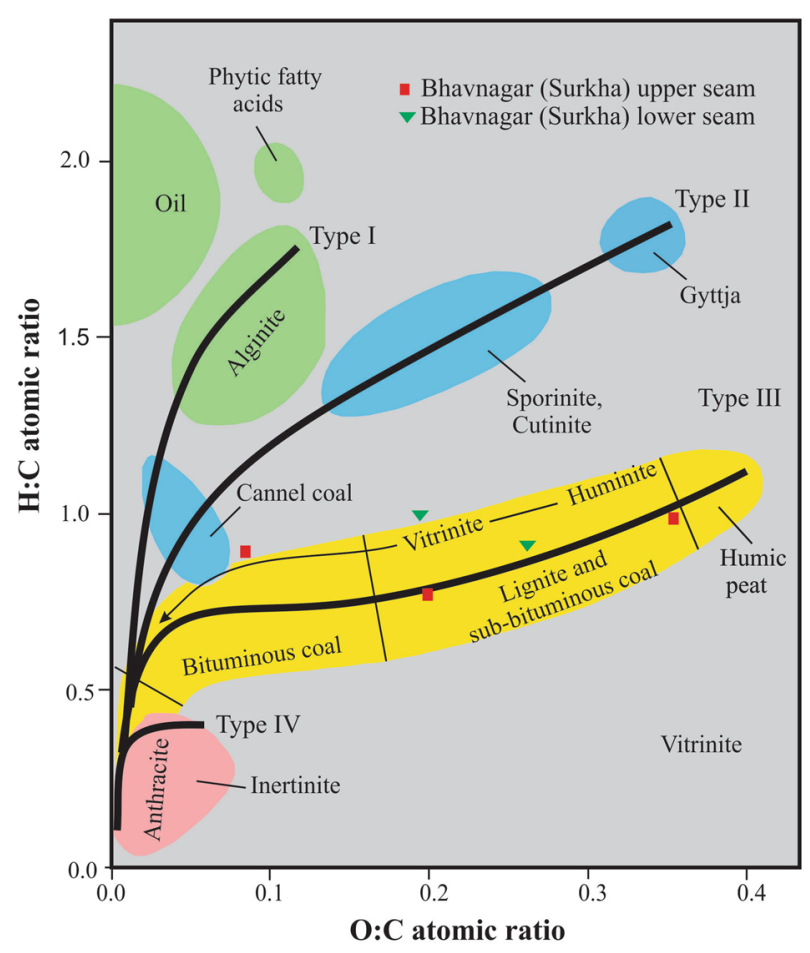

Fig. 5 Cross plot between $\mathrm{H} / \mathrm{C}$ and $\mathrm{O} / \mathrm{C}$ atomic ratio (after Cornelius 1978) 


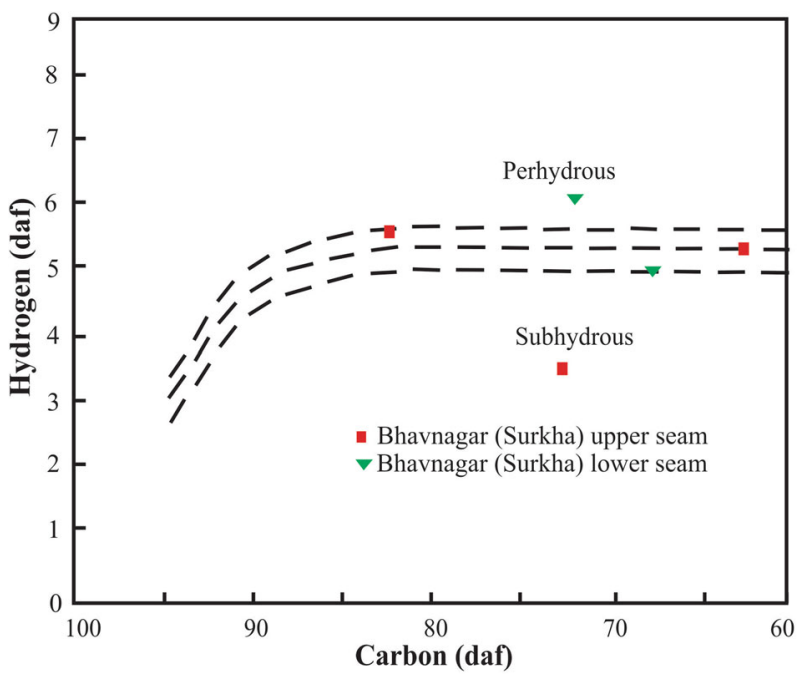

Fig. 6 Carbon and hydrogen content of investigated lignite shown in the simplified Seyler's chart. The 'bright coal band' is indicated by (after Cornelius 1978)

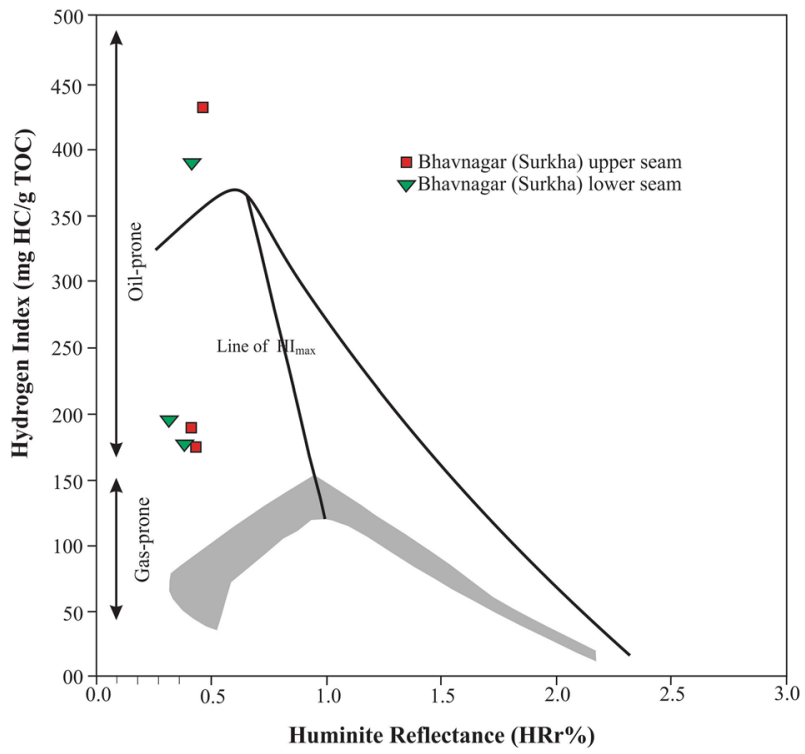

Fig. 7 Cross plot between vitrinite (Huminite) reflectance (HRr) and hydrogen index (HI)of Saurashtra basin lignites. (adopted after Petersen 2005). Coals with $\mathrm{HI}$ value $<150 \mathrm{mg}$ TOC are considered as gas-prone as shown in the shaded line. HI increases towards a maximum at around $0.7 R_{\mathrm{o}} \%$ (as represented by the HI max line) before decreasing significantly after oil window maturity is reached

Hydrogen Index is several folds higher than the Oxygen Index (Table 3). The ternary plot, which is based purely on the maceral composition of these lignites, also favours the generation of lighter hydrocarbons (Fig. 8) and the plot between TOC and $\mathrm{S}_{2}$ (Fig. 9) indicates that these lignites can act as an excellent source for the hydrocarbon generation which is supported by a positive linear correlation $(r=0.680)$ between them.

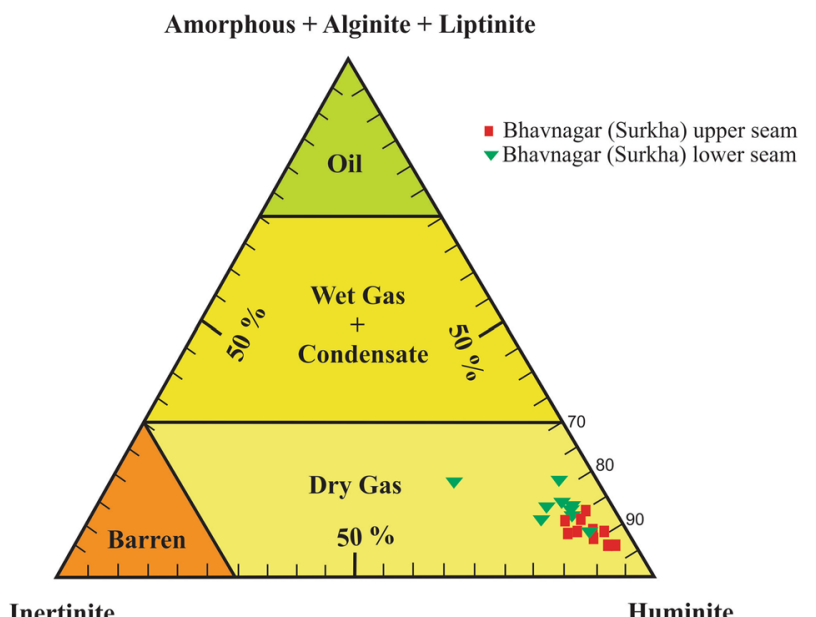

Inertinite

Huminite

Fig. 8 Ternary diagram based on maceral composition indicating the hydrocarbon potential of lignite's of Saurashtra basin (after Tissot and Welte 1984)

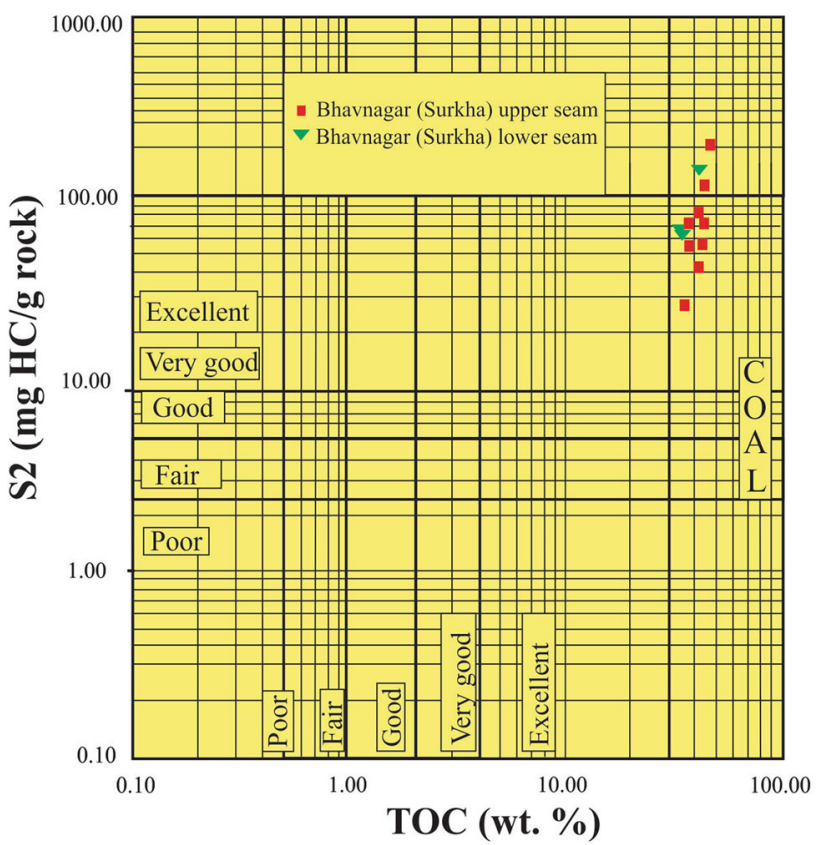

Fig. 9 Cross plot between total organic carbon (TOC) and fixed hydrocarbon potential (S2) of the analysed samples of saurashtra basin (Modified after Peters and Cassa 1994; Dembicki 2009)

Jin and Shi (1997) have used the amount of reactive macerals (RM, which is total of huminite plus liptinite) in various kinds of coal and studied their 'conversion' and 'oil yield'. They have used the following empirical formulae:

Conversion $(\%)=0.2 \mathrm{RM}+76.6$

Oil yield $(\%)=0.22 \mathrm{RM}+44.8$

The reactivity of coal for its liquefaction is also studied by Guyot (1978). He used 'petrofactor' and defined it as: $\mathrm{RF}=1000 R_{\max } / \mathrm{RM}$ where $R_{\max }$ is the maximum 
Table 6 Values of conversion, oil yield and petrofactor calculated for the lignites of Saurashtra basin, Gujarat using empirical formula

\begin{tabular}{|c|c|c|c|c|c|c|c|c|}
\hline \multirow[t]{2}{*}{ S. no. } & \multirow[t]{2}{*}{ Humi (mmf) } & \multirow[t]{2}{*}{ Lipti (mmf) } & \multirow[t]{2}{*}{$\mathrm{RM}$} & \multirow[t]{2}{*}{$R_{\max }$} & \multicolumn{2}{|l|}{ Conversion $\%$} & \multirow[t]{2}{*}{ Oil yield \% } & \multirow[t]{2}{*}{ Petrofactor (RF) } \\
\hline & & & & & Conversion-1 & Conversion-2 & & \\
\hline \multicolumn{9}{|c|}{ Bhavnagar upper seam } \\
\hline BH10 & 83.8 & 10.5 & 94.3 & 0.41 & 95.35 & 95.46 & 65.55 & 4.35 \\
\hline BH9 & 87.5 & 7.5 & 95 & & & 95.6 & 65.7 & \\
\hline BH8 & 81.9 & 9.6 & 91.5 & & & 94.9 & 64.93 & \\
\hline BH7 & 83.5 & 12.9 & 96.4 & & & 95.88 & 66.01 & \\
\hline BH6 & 87.2 & 9.2 & 96.4 & & & 95.88 & 66.01 & \\
\hline BH5 & 83.9 & 9.5 & 93.4 & 0.47 & 94.77 & 95.28 & 65.35 & 5.03 \\
\hline BH4 & 90.8 & 6.1 & 96.9 & & & 95.98 & 66.12 & \\
\hline BH3 & 89.9 & 5.9 & 95.8 & & & 95.76 & 65.88 & \\
\hline $\mathrm{BH} 2$ & 84.2 & 9.2 & 93.4 & & & 95.28 & 65.35 & \\
\hline BH1 & 80.8 & 12.8 & 93.6 & 0.42 & 95.23 & 95.32 & 65.39 & 4.49 \\
\hline Mean & 85.35 & 9.32 & 94.67 & 0.43 & 95.16 & 95.53 & 65.63 & 4.58 \\
\hline \multicolumn{9}{|c|}{ Bhavnagar seam lower } \\
\hline BHL9 & 80 & 14.4 & 94.4 & 0.36 & 95.82 & 95.48 & 65.57 & 3.79 \\
\hline BHL8 & 74.8 & 18.1 & 92.9 & & & 95.18 & 65.24 & \\
\hline BHL7 & 75.5 & 13.6 & 89.1 & & & 94.42 & 64.4 & \\
\hline BHL6 & 57.1 & 17.9 & 75 & & & 91.6 & 61.3 & \\
\hline BHL5 & 76.8 & 10.5 & 87.3 & 0.42 & 94.98 & 94.06 & 64.01 & 4.79 \\
\hline BHL4 & 85.6 & 8.8 & 94.4 & & & 95.48 & 65.57 & \\
\hline BHL3 & 78.6 & 14.8 & 93.4 & & & 95.28 & 65.35 & \\
\hline BHL2 & 79 & 12.1 & 91.1 & & & 94.82 & 64.84 & \\
\hline BHL1 & 80.5 & 13.3 & 93.8 & 0.44 & 95.06 & 95.36 & 65.44 & 4.69 \\
\hline Mean & 76.43 & 13.72 & 90.16 & 0.41 & 95.22 & 94.63 & 64.63 & 4.5 \\
\hline
\end{tabular}

Conversion-1 = 99-0.84 RF (Jin and Shi 1997); Conversion-2 = 0.2 RM + 76.6 (Guyot 1978); Oil yield \% = 0.22 RM + 44.8, Petrofactor $(\mathrm{RF})=1000 R_{\max } / \mathrm{RM}$

reflectance of vitrinite. The lignites of Saurashtra basin are very high in reactive maceral content which plays a significant role in hydrogenation or liquefaction of coal/lignite. The reactive macerals in the upper seam vary from $91.5 \%$ to $96.9 \%$ while from $75.0 \%$ to $94.4 \%$ in lower seam (Table 6). The 'conversion' and 'oil yield' of the lignites of Saurashtra basin have been calculated (Table 6) using empirically derived equations of Guyot (1978) and Jin and Shi (1997).

A strong positive linear correlation between conversion and huminite $(r=0.916)$ indicates of the significance of this maceral in liquefaction. The role of petrofactor has also been observed in liquefaction of Gujarat lignites. Petrofactor holds a relation with conversion $(r=-0.419)$ and with oil yield $(r=-0.419)$ whereas it maintains a positive linear correlation with carbon $(r=0.73)$. The conversion values of these lignites are high $(94.63 \%$ $95.53 \%)$ and the oil yield $(64.63 \%-65.63 \%)$ is also significant (Table 6). The empirically derived values are validated by the Rock-Eval data and reveal a high hydrocarbon generating potential of these lignite resources. A strong sympathetic correlation $(r=0.999)$ exists between conversion and oil yield which complements each other. Thus, the maceral composition of the lignites of the Saurashtra basin and their maturity indicate that they may be potentially utilized through liquefaction. Nevertheless, a pilot scale study is recommended before taking any strategic decision in future.

\section{Conclusions}

Based on the present investigation, following conclusions are drawn:

1. Saurashtra lignites are characterized by high moisture, low to moderate ash yield and high volatile matter. Huminite is the predominantly occurring maceral group whilst liptinite and inertinite groups subordinate the list. Huminite is mainly represented by detrohuminite followed by telohuminite.

2. These lignites have moderately high TOC (av. 40.16\%) and their maturity is low which is reflected by its $T_{\max }$ 
(av. $416.23{ }^{\circ} \mathrm{C}$ ) and huminite reflectivity $(0.28 \%-$ $0.30 \%)$. The organic matter is dominated by kerogen Type-III with a little amount of kerogen Type-II. The oil-prone nature is revealed by the cross plot between vitrinite reflectance and hydrogen index. Fixed hydrocarbon is many folds higher than free hydrocarbons.

3. These lignites are high in reactive maceral content (90.16\%-94.67\%). A high 'conversion' and 'oil yield' values of the lignites were empirically observed which also validate the Rock-Eval data.

Acknowledgements The authors thankfully acknowledge the Department of Geology, Banaras Hindu University for extending the laboratory and other facilities and to the National Metallurgical Laboratory, Jamshedpur for permission to take vitrinite reflectance measurements. The Rock-Eval pyrolysis has been carried out by Oil India Limited. The help rendered by the officials in the Surkha mine is thankfully acknowledged. The author (PKS) is highly indebted to his friend, philosopher and guide late Prof. M. P. Singh who left for heavenly abode on 13th April, 2017. He has been the true source of inspiration throughout. We extend our thankfulness to the two anonymous reviewers for their constructive criticism.

Open Access This article is distributed under the terms of the Creative Commons Attribution 4.0 International License (http://crea tivecommons.org/licenses/by/4.0/), which permits unrestricted use, distribution, and reproduction in any medium, provided you give appropriate credit to the original author(s) and the source, provide a link to the Creative Commons license, and indicate if changes were made.

\section{References}

Amijaya H, Littke R (2005) Microfacies and depositional environment of Tertiary Tanjung Enim low rank coal, South Sumatra basin, Indonesia. Int J Coal Geol 61:197-221

Baruah BP, Sharma A, Saikia BK (2013) Petro-chemical investigation of some perhydrous Indian coals. J Geol Soc India 81(5):713718

Biswas SK (1982) Rift basins in western margin of India and their hydrocarbon prospects with special reference to Kutch basin. Am Assoc Petrol Geol Bull 64:209-220

Cornelius CD (1978) Muttergesteinfazies als Parameter der Erdölbildung. Erdö 1-Erdgas Zeitschrift 3:90-94

Cudmore JF (1977) Evaluation of coals for conversion to liquid hydrocarbons. In: Australian institute of mining and metallurgy on coal borehole evaluation. pp. 146-158

Dembicki H (2009) Three common source rock evaluation errors made by geologists during prospect or play appraisals. Am Assoc Petrol Geol Bull 93:341-356

Dow WG (1974) Application of oil correlation source rock data to exploration in Williston basin. AAPG Bull 58:1253-1262

GSI (2012) Geological and mineral map of Gujarat, Daman and Diu (Published under the Direction of the Director General, Geol Surv India; Government of India Copyright 2012)

Guyot RE (1978) Influence of coal characteristics on the yields and properties of hydrogenation products, ACIRL-PR-78-8. Australian Coal Industry Research Laboratories, North Ryde, NSW, Australia

Haq BU, Hardenbol J, Vail PR (1987) Chronology of fluctuating sea levels since the Triassic. Science 235:1156-1167
ICCP (2001) The new inertinite classification (ICCP System 1994). Fue 80:459-471

ISO 11760 (2005) Classification of coals. International standard: 1-9

Jin J, Shi S (1997) The development and prospective application of coal direct liquefaction for Chinese coals. In: Proceedings of the international symposium on clean coal technology. China Coal Industry Publishing House, Xiamen, p 379

Katz ME, Pak DK, Dickens GR, Miller KG (1999) The source and fate of massive carbon input during the Latest Paleocene thermal maximum. Science 286:1531-1533

Kennet JP, Stott LD (1991) Abrupt deep sea warming, paleooceanogrphic changes and benthic extinction at the end of the Paleocene. Nat 353:225-229

Koch PL, Zachos JC, Gingerich PD (1992) Correlation between isotope records in marine and continental reservoirs near the Paleocene-Eocene boundary. Nat 258:319-322

Koeverdon JHV, Karlsen DA, Backer-Owe K (2011) Carboniferous non-marine source rocks from Spitsbergen and Bajornoya: comparison with western Arctic. J Petrol Geol 34(1):53-66

Macgregar DS (1994) Coal-bearing strata as source rocks-A global overview. In: Scott AC and Fleet AJ (eds) Coal and Coal-bearing Strata as Oil-prone Source Rocks? Geological Society, London, Special Publications 77(1):1-6

Mukhopadhyay PK, Hatcher PG, Calder JH (1991) Hydrocarbon generation from eltaic and intermontane fluviodeltaic coal and coaly shale from the Tertiary of Texas and Carboniferous of Nova Scotia. Org Geochem 17:765-783

Noble RA, Wu CH, Atkinson CD (1991) Petroleum generation and migration from Talang Akar coals and shales offshore N.W. Java, Indonesia. Org Geochem 17:363-374

Otis RM, Schneidermann N (1997) A process for evaluating exploration prospects. AAPG Bull 81:1087-1109

Peters KE (1986) Guidelines for evaluating petroleum source rock using programmed pyrolysis. AAPG Bull 70(3):318-329

Peters KE, Cassa MR (1994) Applied source rock geochemistry. In: Magoon LB,Dow WG (eds) The petroleum system from source to trap. AAPG Memo 60:93-120

Petersen HI (2005) Oil Generation from coal source rocks: the influence of depositional conditions and stratigraphic age. Geol Sur Denmark Greenland Bull 7:9-12

Petersen HI (2006) The petroleum generation potential and effective oil window of humic coals related to coal composition and age. Int J Coal Geol 67(4):221-248

Petersen HI, Rosenberg P, Andsbjerg J (1996) Organic geochemistry in relation to the depositional environments of Middle Jurassic coal seams, Danish Central Graben, and implications for hydrocarbon generative potential. Am Assoc Petrol Geol Bull $80: 47-62$

Petersen HI, Andsbjerg J, Bojesen-Koefoed JA, Nytoft HP, Rosenberg P (1998) Petroleum potential and depositional environments of Middle Jurassic coals and non-marine deposits, Danish Central Graben, with special reference to the Sogne Basin. Geol Surv Den Greenl, Bull, p 36

Powell TG, Boreham CJ (1994) Terrestrial sourced oils: where do they exist and what are our limits of knowledge? A geochemical perspective. Geol Soc London Spec Pap 77(1):11-29

Raju SV, Mathur N (2013) Rajasthan lignite as a source of unconventional oil. Curr Sci 104(6):752-757

Sahni A, Saraswati PK, Rana RS, Kishor K, Singh H, Alimohammadian H, Sahni N, Rose KD, Singh L, Smith T (2006) Temporal constraints and depositional paleoenvironmnets of the Vastan lignite sequences, Gujarat: analogy for Cambay shale hydrocarbon source rock. Ind J Petrol Geol 15:1-20

Samant B (2000) Palynostratigraphy and age of the Bhavnagar lignite, Gujarat, India. Palaeobot 49:101-118 
Schmitz B, Pujalte V, Nunez-Betelu K (2001) Climatic and sea level perturbations during the initial Eocene Thermal Maximum: evidence from siliciclastic units in the Basque Basin (Urmua, Zumaia and the Trabakua Pass), northern Spain. Paleogeo Paleocl Paleoeco 165:299-320

Schopf JM (1960). In: Taylor GH, Teichmüller M, Davis A, Diessel CFK, Littke R, Robert P (eds) Organic Petrology (1998). Gebrüder Borntraeger, Berlin, p 704

Sharma A, Saikia BK, Phukan S, Baruah BP (2016) Petrographical and thermo-chemical investigation of some North East Indian high sulphur coals. J Geol Soc India 88(5):609-619

Singh PK (2012) Petrological and geochemical considerations to predict oil potential of Rajpardi and Vastan Lignite Deposits of Gujarat, Western India. J Geol Soc India 80:759-770

Singh A, Singh BD (2005) Petrology of Panandhro lignite deposit, Gujarat in relation to palaeodepositional condition. J Geol Soc India 66:334-344

Singh PK, Singh MP, Singh AK (2010a) Petro-chemical characterization and evolution of Vastan Lignite, Gujarat, India. Int J Coal Geol 82:1-16

Singh PK, Singh MP, Singh AK, Arora M (2010b) Petrographic characteristics of coal from the Lati Formation, Tarakan basin, East Kalimantan. Int J Coal Geol 81:109-116

Singh PK, Singh MP, Singh AK, Naik AS, Singh VK, Singh VK, Rajak PK (2012a) Petrological and geochemical investigations of Rajpardi lignite deposit, Gujarat, India. Energy Explor Exploit 30:131-152

Singh PK, Singh MP, Singh AK, Naik AS (2012b) Petrographic and geochemical characterization of coals from Tiru valley, Nagaland, NE India. Energy Explor Exploit 30:171-192

Singh PK, Singh MP, Singh AK, Arora M, Naik AS (2013) The prediction of the liquefaction behavior of the East Kalimantan coals of Indonesia: an appraisal through petrography of selected coal samples. Energy Sources Part A 35:1728-1740

Singh PK, Singh VK, Rajak PK, Singh MP, Naik AS (2016a) Distribution and geochemistry of selected trace elements in the lignites of Cambay basin, Gujarat, Western India. J Geol Soc India 88:1-16

Singh PK, Rajak PK, Singh VK, Singh MP, Naik AS, Raju SV (2016b) Studies on thermal maturity and hydrocarbon potential of lignites of Bikaner-Nagaur basin, Rajasthan. Energy Explor Exploit 34:140-157

Singh PK, Singh VK, Rajak PK, Singh MP, Naik AS, Raju SV, Mohanty D (2016c) Eocene lignites from Cambay basin, Western India: an excellent source of hydrocarbon. Geosc Front 7:811-819

Singh PK, Singh VK, Singh MP, Rajak PK, Naik AS (2017a) Paleomires of Eocene lignites of Bhavnagar, Saurashtra basin (Gujarat), Western India: petrographic implications. J Geol Soc India 90:9-19

Singh PK, Singh VK, Singh MP, Rajak PK (2017b) Understanding the paleomires of Eocene lignites of Kachchh Basin, Gujarat (Western India): petrological implications. Int J Coal Sci Tech 4 (2):80-101

Singh PK, Singh VK, Singh MP, Rajak PK (2017c) Petrographic characteristics and Paleoenvironmental history of Eocene lignites of Cambay basin, Western India. Int J Coal Sci Tech 4 (3):214-233

Srivastava PK (1963) Geology of Saurashtra. Oil and Natural Gas Corporation Report, Unpublished

Suárez-Ruiz I, Crelling J (2008) Applied coal petrology: the role of petrology in coal utilization. Academic Press, Cambridge, p 388

SY'Korova I, Pickel W, Christanis M, Wolf K, Taylor GH, Flores D (2005) Classification of huminite. ICCP System 1994. Int J Coal Geol 62:85-106

Taylor GH, Teichmüller M, Davis A, Diessel CFK, Littke R, Robert P (1998) Organic Petrology. Gebrüder Borntraeger, Berlin, p 704

Teichmüller M, Teichmüller R, Bartenstein H (1984) Inkohlung und Erdgas-eine neue Inkohlungskarte der Karbonoberflache in Nordwest-deutschland. Fortschr Geol Rheinld Westf 32:11-34

Thakur OP, Singh A, Singh BD (2010) Petrographic Characterization of Khadsaliya Lignites, Bhavnagar District, Gujarat. J Geol Soc India 76:40-46

Thomas L (2002) Coal Geology. Willey, Ltd, p 384

Tissot BP, Welte DH (1984) Petroleum formation and occurrence, 2nd edn. Springer, Berlin, p 699

Wilkins RWT, George SC (2002) Coal as a source rock for oil: a review. Int J Coal Geol 50:317-361 